Vesna Dickov ${ }^{1}$

Universidad de Belgrado

Facultad de Filología
UDK: 016:929 Pavlović-Samurović Lj.

https://doi.org/10.18485/imp.2017.ch.19

\title{
LJILJANA PAVLOVIĆ-SAMUROVIĆ: DESARROLLO Y PERSPECTIVAS DE LOS ESTUDIOS HISPANO-ESLAVOS EN SERBIA
}

La doctora Ljiljana Pavlović-Samurović fue la primera catedrática de filología hispánica de la Universidad de Belgrado en Serbia y fundadora del Departamento de Lengua Española y Literaturas Hispánicas y de la Cátedra de Estudios Ibéricos de la Facultad de Filología de la misma Universidad. Se dedicaba mayormente a los estudios de la literatura hispánica, tanto la española, sobre todo la literatura del Siglo de Oro y la obra de Miguel de Cervantes Saavedra, como la literatura hispanoamericana, desde los puntos de vista de la historia de literatura y de la valoración crítica. Un campo especial de su interés representan los estudios hispano-eslavos que desarrollaba dentro de sus actividades académicas relacionadas con las Reuniones Científicas Internacionales de los Eslavistas en los Días de Vuk organizados por el Centro Internacional Eslavo de la Facultad de Filología de Belgrado. El propósito del presente trabajo es analizar - aplicando el método analítico - los artículos escritos por la profesora Ljiljana Pavlović-Samurović que fueron publicados en las Actas de las Reuniones Científicas Internacionales de los Eslavistas en los Días de Vuk, con el objetivo de extraer las conclusiones sintéticas sobre su influjo en el desarrollo de los estudios hispano-eslavos en Serbia, así como sobre la existencia de perspectivas para su evolución en el futuro.

Palabras clave: Ljiljana Pavlović-Samurović (1935-2006), hispanismo en Serbia, Universidad de Belgrado, Facultad de Filología, Cátedra de Estudios Ibéricos, Departamento de Lengua Española y Literaturas Hispánicas, estudios hispano-eslavos, Centro Internacional Eslavo, Reuniones Científicas Internacionales de los Eslavistas en los Días de Vuk.

Ljiljana Pavlović-Samurović nació el 23 de julio de 1935 en Belgrado donde terminó la escuela elemental y también la secundaria. Se graduó 
de la Lengua y Literatura Francesa en la Facultad de Filosofía y Letras en 1959, después de lo cual se fue a Francia donde continuó su educación en el Instituto de Estudios Hispánicos de la Facultad de Letras y Ciencias Humanas de la Universidad de París, la Sorbona, en el que obtuvo, durante ese mismo año, el certificado de la literatura española. A partir de ese momento, el desarrollo profesional de Ljiljana Pavlović-Samurović estuvo muy estrechamente vinculado con el desarrollo de los estudios hispánicos en la Facultad de Filología de la Universidad de Belgrado.

En 1962, Ljiljana Pavlović-Samurović acabó sus estudios de postgrado en la Facultad de Filología de Belgrado y llegó a ser profesora ayudante de la lengua española, cuya enseñanza como materia curricular de dos años ${ }^{2}$ comenzó durante el curso académico 1962/1963 en la Cátedra de Estudios Románicos de la Facultad de Filología de la Universidad de Belgrado.

Gracias a la beca del Gobierno de México, Ljiljana Pavlović-Samurović ejerció las investigaciones para su tesis doctoral en el transcurso de seis meses del año 1964, bajo la supervisión de la profesora doctora María del Carmen Millán, en el Centro de Estudios Literarios de la Facultad de Filosofía y Letras de la Universidad Nacional Autónoma de México.

Aprobó en diciembre de 1965 en la Sorbona los exámenes de doctorado de la literatura hispanoamericana contemporánea y la técnica de investigaciones científicas, donde también defendió el 25 de junio de 1966 con honores („cum laude“) su tesis de doctorado denominada Las literaturas hispanoamericanas en "Mercure de France" (1897-1915) que fue dirigida por el doctor Charles Aubrun, profesor de estudios hispánicos y director del Instituto de Estudios Hispánicos en la Universidad de París. La tesis de la doctora Ljiljana Pavlović-Samurović fue validada en la Facultad de Filología de Belgrado al año siguiente (1967) y publicada dos años después (1969) por la dicha institución, mientras que en París apareció (1971) como el fruto de la actividad editorial común de la Universidad de Belgrado y la Sorbone.

En marzo de 1970, la doctora Ljiljana Pavlović-Samurović fue nom-

2

La enseñanza del idioma español en la Universidad de Belgrado empezó a realizarse en la Facultad de Filosofía y Letras al nivel facultativo en 1951; el primer maestro fue un emigrado republicano español José Bort-Vela. 
LJILJANA PAVLOVIĆ-SAMUROVIĆ: DESARROLLO Y PERSPECTIVAS DE LOS ESTUDIOS...

brada Profesora Asociada de la Facultad de Filología de Belgrado. Muy poco tiempo después, en 1971 fue fundado el Departamento de Lengua y Literatura Españolas dentro del marco de la Cátedra de Estudios Románicos de la Facultad de Filología de la Universidad de Belgrado, y la lengua y letras españolas empezaron a enseñarse como carrera universitaria de cuatro años.

La doctora Ljiljana Pavlović-Samurović llegó a ser Profesora Titular en 1979. Al introducir la materia Literatura Hispanoamericana en 1980, la carrera empezó a llamarse Lengua Española y Literaturas Hispánicas. En 1984, la doctora Ljiljana Pavlović-Samurović fue elegida catedrática. Gracias a los nuevos Estatutos de la Facultad de Filología de la Universidad de Belgrado que fueron aprobados en 2000, empezó a existir independientemente la Cátedra de los Estudios Ibéricos, que en la actualidad se compone del Departamento de Lengua Española y Literaturas Hispánicas, del Lectorado de Portugués ${ }^{3}$ y del Lectorado de Catalán ${ }^{4}$. Después de la jubilación, la doctora Ljiljana Pavlović-Samurović ejerció actividades científicas con mucha diligencia y entusiasmo hasta su muerte repentina que ocurrió el 3 de marzo de 2006.

A lo largo de casi cuarenta años de su carrera académica, la doctora Ljiljana Pavlović-Samurović se dedicó a varios campos de investigación dentro del marco de los estudios hispánicos (v. Dickov 2005, 2014). En 1974, preparó la selección de poemas de los poetas modernos de la América Latina bajo el título Las luces de las Cordilleras: la antología de la poesía hispanoamericana: 1920-1972 (Светлости Кордиљера: антологија хиспаноамеричке поезије: 1920-1972). Desde el punto de vista de la historia de literatura, a la profesora Pavlović-Samurović le interesaba especialmente la obra literaria de Miguel de Cervantes Saavedra, de lo cual como la prueba sirven sus libros Don Quijote de Miguel de Cervantes (Дон Кихот Мигела де Сервантеса, 1982) у El libro sobre Cervantes (Књига о Сервантесу, primera edición 2002; segunda edición aumentada 2004).

3 El Lectorado de Portugués fue establecido en la Facultad de Filología de Belgrado en 1997, pero su funcionamiento fue interrumpido en 1999 y, luego, fue reestablecido en el año académico 2005/2006.

$4 \quad$ El Lectorado de Catalán existe en la Facultad de Filología de Belgrado desde el año académico 2005/2006. 
También publicó, junto con el profesor Dalibor Soldatić, el libro La literatura española I (Шпанска књижевност I, 1985), siendo la autora de las siguientes partes: “La literatura medieval y prerrenacentista: géneros у еspecies” („Средњевековна и предренесансна књижевност: родови и врсте, 9-203) у “Cervantes” („Сервантес“, 275-318). Sin duda alguna, la obra capital de la doctora Ljiljana Pavlović-Samurović es El diccionario de la literatura hispanoamericana (Leksikon hispanoameričke književnosti, 1993), por el cual fue galardonada por la Comunidad Cultural-Educativa de Belgrado con el Premio "Anillo de Oro" ("Zlatni beočug").

Los estudios de carácter comparativo sobre las relaciones entre la filología hispánica y la filología serbia, llevados a cabo por la profesora Pavlović-Samurović durante muchos años, se refieren mayormente a su actividad vinculada con el Centro Internacional Eslavo de la Facultad de Filología de la Universidad de Belgrado, que representa la institución de este tipo con la tradición más larga en el mundo eslavo entero 5 . La doctora Ljiljana Pavlović-Samuroviić participaba frecuentemente en las Reuniones Científicas Internacionales de los Eslavistas en los Días de Vuk, organizadas anualmente por dicho Centro, en las cuales presentaba sus ponencias que se encuentran en el foco de nuestra observación crítica en el presente trabajo, hecha de modo analítico y de acuerdo con el criterio cronológico.

La profesora Ljiljana Pavlović-Samurović empezó su colaboración con el Centro Internacional Eslavo de la Facultad de Filología de Belgrado en 1974 cuando intervino en la IV Reunión Científica Internacional de los Eslavistas en los Días de Vuk con su ponencia "El motivo de la doncella-guerrera en el Romancero español y nuestra poesía popular” („Мотив девојке-ратника у шпанском Романсеру и у нашој народној поезији"). La autora encuentra las fuentes para su investigación en la obra de Ramón Menéndez Pidal (Flor nueva de romances viejos) y en los estudios comparativos elaborados por los especialistas de ex-Yugoslavia (Ante Tresić Pavičić, Olinko Delorko, Ivan Slamnig, Valtazar Bogišić, Maja Bošković-StuIli, Nikola Andrić). Tomando en cuenta los rasgos principales del romance, género muy popular desde el siglo XV hasta la época contemporánea,

5 El Centro Internacional Eslavo de la Facultad de Filología de la Universidad de Belgrado fue fundado en 1970 . 
LJILJANA PAVLOVIĆ-SAMUROVIĆ: DESARROLLO Y PERSPECTIVAS DE LOS ESTUDIOS...

tanto en España como en la América Latina, los países mediterráneos y los países del antiguo imperio otomano, Ljiljana Pavlović-Samurović primero analiza detalladamente el romance "La doncella guerrera" del siglo XVI y luego lo compara con la canción narrativa "Jele Šćepanova" que fue registrada por Baldo Glavić en la isla de Korčula durante la segunda mitad del siglo XIX. Según los resultados obtenidos que apuntan a muchas similitudes (el motivo, los personajes, la estructura, la distribución de los diálogos, la cronología de los eventos) y algunas diferencias (la longitud, la concepción psicológica de los personajes) entre ambos poemas, la profesora Pavlović-Samurović (1974: 265) se dirige hacia la investigación de la influencia probable del romance español sobre la creación de la canción narrativa croata. En base de un antiguo romance sefardí, que fue colectado por Kalmi Baruh en los años treinta del siglo pasado, la profesora Pavlović-Samurović (1974: 267) sugiere la posibilidad de aparición del romance español "La doncella guerrera" en el ambiente cultural yugoslavo; los caminos probables de su infiltración cruzaban Bosnia y Dalmacia, es decir aquellas regiones de la ex-Yugoslavia donde se encontraban fuertes comunidades sefardíes.

En la V Reunión Científica Internacional de los Eslavistas en los Días de Vuk, la profesora Pavlović-Samurović (1975) presentó su ponencia bajo el título "Los textos sobre la literatura española publicados en Letopis en el transcurso de las primeras cuatro décadas del siglo XX" („Написи о шпанској књижевности објављени у Летопису у току прве четири деценије XX века“). Al llevar a cabo la investigación relacionada con dicho aspecto de la recepción de la literatura española en Serbia, la autora (Samurović-Pavlović 1975: 317) señala en la parte introductoria de su estudio que los resultados obtenidos inducen doble impresión: la satisfacción por la existencia de ese tipo de textos en aquel tiempo a diferencia de su ausencia total en el siglo XIX y, simultáneamente, la decepción por el pequeño número de los artículos mencionados. Se trata de cuatro textos, de los cuales dos son cortos y tienen carácter informativo (uno dedicado a Miguel de Unamuno y otro a Pedro Calderón de la Barca), mientras que otros dos son los ensayos escritos por Marko Car. El primer ensayo de Car, publicado en 1901, representa el "perfil literario" de Ramón de Campoamor y el segundo, que apareció en Letopis en 1939, consta de dos 
análisis paralelos: uno sobre los valores estéticos y filosóficos del Don Quijote de Miguel de Cervantes Saavedra y otro sobre la primera traducción de esta obra maestra al serbio, hecha por Đorđe Popović-Daničar y publicada por la primera vez en 1895-1896. Ljiljana Pavlović-Samurović analiza cautelosamente ambos ensayos de Marko Car, menciona su conocimiento de las lenguas extranjeras (francés, italiano, español) así que las fuentes utilizadas, comenta sus traducciones de algunos poemas de Campoamor al serbio, destaca los juicios propios de Car sobre la traducción de Đorđe Popović-Daničar y concluye que los artículos sobre la literatura española, publicados en Letopis, aunque son reducidos, comprueban que la literatura española estuvo presente de vez en cuando en la revista literaria serbia más antigua.

El interés de la profesora Pavlović-Samurović por los estudios de Ramón Menéndez Pidal sobre la literatura tradicional, que se despertó a comienzos de los años setenta, fue profundizado en su ponencia "Una opinión de Menéndez Pidal sobre la poesía oral yugoslava” („Једно мишљење Менендеса Пидала о југословенској усменој поезији“), preparada en 1976 para la VI Reunión Científica Internacional de los Eslavistas en los Días de Vuk. La autora analiza la comunicación que Menéndez Pidal presentó en 1964 en el Congreso Internacional de la Sociedad Rencesvals en Barcelona bajo el título "Los cantores épicos yugoeslavos y los occidentales. El Mío Cid y dos refundidores primitivos" sobre las semejanzas y diferencias entre los cantores yugoslavos contemporáneos y los juglares españoles medievales. Tomando en cuenta que Ramón Menéndez Pidal utilizaba los estudios de otros autores (Albert Lord, Maurice Delbouille) dedicados a la tradición oral en la ex-Yugoslavia, la profesora Pavlović-Samurović supone que el gran científico español probablemente no tenía los conocimientos directos de la poesía épica yugoslava. Menéndez Pidal critica el papel excesivo de la improvisación en el proceso de trasmisión oral e insiste en la diferencia entre la improvisación y la variante de una canción o sea sus refundiciones, ya que "la canción tradicional oral vive en variantes y se rejuvenece y crece en refundiciones" (Pavlović-Samurović 1976: 133).

A principios de los años ochenta, el estudio sistemático de la literatura española se profundizaba intensivamente en la ex-Yugoslavia, espe- 
LIILJANA PAVLOVIĆ-SAMUROVIĆ: DESARROLLO Y PERSPECTIVAS DE LOS ESTUDIOS...

cialmente aquel de la tradición oral, y con frecuencia se planteaban los problemas de la traducción de algunos términos literario-teóricos y literario-históricos específicos. Debido a estas necesidades, la profesora Ljiljana Pavlović-Samurović llevó a cabo investigaciones cuyos resultados presentaba en las Reuniones Científicas Internacionales de los Eslavistas en los Días de Vuk organizadas por el Centro Internacional Eslavo de la Facultad de Filología de la Universidad de Belgrado.

La primera de estas ponencias de la profesora Pavlović-Samurović (1980) tiene el título "Sobre la traducción al serbo-croata del sustantivo español el romance” („О превођењу шпанске именице el romance на српскохрватски језик") у соmprende un panorama crítico de las soluciones ofrecidas por varios historiadores y teóricos de literatura de la ex-Yugoslavia (Svetozar Petrović, Kalmi Baruh, Radmilo Dimitrijević, Dragiša Živković, Maja Bošković-Stulli, Olinko Delorko, Ivan Slamnig, Milivoj Solar), así como las interpretaciones del término romance dadas en diferentes diccionarios publicados en Serbia y Croacia durante el siglo XX ( Diccionario de la lengua serbo-croata literaria de Matica Srpska, Diccionario literario de Tvrtko Čubelić, Diccionario de los géneros de la literatura oral de Nada Milošević-Đorđević, Diccionario de palabras y expresiones extranjeras de Milan Vujaklija). Al analizar las variantes (романса, романца, шпанска романса, балада) que se pueden encontrar en uso en la práctica serbo-croata para el término español el romance, la profesora Pavlović-Samurović (1980: 198-199) recomienda la aplicación del sintagma шпанска романса en los textos que no son exclusivamente dedicados a la literatura española a fin de distinguir este género español de los parecidos, pero no idénticos, géneros que existen en la tradición yugoslava.

En la ponencia "Sobre la traducción de los términos españoles el juglar y lo juglaresco al idioma serbocroata” („О превођењу шпанских термина juglar и juglaresco на српскохрватски језик"), la profesora Ljiljana Pavlović-Samurović (1981) parte de la etimología del sustantivo juglar, dada en el Diccionario crítico-etimológico de la lengua castellana de Joan Corominas y del análisis del papel muy complejo que el juglar tenía en la sociedad medieval española, presentado en las obras de Ramón Menéndez Pidal. Después de revisar las acepciones de los términos en serbo- 
croata (žongler, narodni pevač, epski pevač), posiblemente adecuados al término español juglar, que se pueden encontrar en las obras relevantes de los científicos yugoslavos (Vojmir Vinja, Nikola Milićević, Tvrtko Čubelić, Vido Latković, Milan Vujaklija), la autora llega a la conclusión de que ninguno de estos términos corresponde con exactitud al concepto del juglar. Por lo tanto, la profesora Pavlović-Samurović (1981: 148) propone, aunque sea una solución temporal, el uso de la transcripción del dicho término español al serbocroata (huglar, huglarski).

Teniendo en cuenta las obras de especialistas renombrados de la región de ex-Yugoslavia (Mila Stojnić, Vladimir Ivir, Miodrag Sibinović) en los cuales se acentúa la necesidad de que el traductor conozca la cultura del pueblo al que pertenece el texto literario que se traduce a fin de obtener una traducción correcta, Ljiljana Pavlović-Samurović escribió su ponencia "Traducción de los términos españoles relativos a los géneros de la prosa al idioma serbocroata (fábula y novela)" („Превођење шпанских термина за прозне врсте на српскохрватски језик [fábula и novela]"). En este estudio se destaca la importancia de que el traductor traduzca con extrema cautela el término de un género literario, sobre todo si se trata de un texto clásico, tomando en consideración el carácter diacrónico de ciertos términos relevantes a la prosa española (Pavlović-Samurović 1982: 99). La atención de la autora está prestada especialmente a los términos fábula y novela que han ido cambiando su significado a lo largo de los siglos: los términos españoles fábula y novela se utilizaban como sinónimos en la obra de Don Juan Manuel (1282-1348), mientras que cuento y novela eran sinónimos en la época anterior a Cervantes (1547-1616). Los términos españoles fábula y novela y los términos serbocroatas fábula y novela representan equivalentes falsos con coincidencia de significado (faux amis), lo que la profesora Pavlović-Samurović (1982: 97-103) comprueba a través de un análisis lingüístico detallado y, consecutivamente, propone el uso de los diccionarios etimológicos y los diccionarios de términos literarios españoles junto con el Diccionario de la Real Academia Española y los diccionarios bilingües con el objetivo de evitar las traducciones erróneas.

A principios de la novena década del siglo XX, la profesora Ljiljana Pavlović-Samurović empieza a ocuparse de la recepción de la obra de Ivo Andrić en España. El resultado de este interés suyo es la ponencia titulada 
LJILJANA PAVLOVIĆ-SAMUROVIĆ: DESARROLLO Y PERSPECTIVAS DE LOS ESTUDIOS...

"Contribución al estudio literario-lingüístico de la obra de Ivo Andrić y sus traducciones en España” („Прилог књижевно-језичком проучавању Андрићевих дела и њихово превођење у Шпанији“) (Pavlović-Samurović 1983), que presentó en la XIII Reunión Científica Internacional de los Eslavistas en los Días de Vuk. Entre los pocos textos dedicados a este escritor nuestro que aparecieron hasta aquella fecha en España, la profesora Pavlović-Samurović elige e interpreta el ensayo "Los sefardíes en una novela de Ivo Andrić", escrito por el distinguido profesor Manuel Álvar. En este breve estudio, Álvar analiza sólo un aspecto de la novela más famosa de Ivo Andrić El puente sobre el Drina - la manera según la cual está presentada la vida, las costumbres y el habla de los judíos sefardíes que han estado viviendo en Bosnia a lo largo de varios siglos después de haber sido expulsados de España en 1942 por los Reyes Católicos. Al comparar el cuadro de la comunidad sefardí dada en la novela de Ivo Andrić con los datos hallados en la literatura científica sobre Bosnia y Balcanes, en la cual figuran las obras de dos filólogos sefardíes de la ex-Yugoslavia Kalmi Baruh y Moris Levi, Manuel Álvar concluye que Andrić ha sabido dar vida en forma artística a los personajes que, sin duda alguna, han existido en determinadas condiciones sociales e históricas (Pavlović-Samurović 1983: 114). Al final de la ponencia, se encuentra la lista de las obras de Ivo Andrić traducidas y publicadas en España que fue confeccionada por la profesora Ljiljana Pavlović-Samurović sobre la base de las investigaciones que realizó en la Biblioteca Nacional en Madrid y los datos de los que disponían la Fundación y el Museo de Ivo Andrić en Belgrado.

Dentro del marco de los estudios realizados por la profesora Pavlović-Samurović para el Centro Internacional Eslavo de la Facultad de Filología de Belgrado, cabe también la ponencia "Calila y Dimna y Stefanit i Ihnilat - contribución al estudio comparado de la fábula medieval española y serbia” („Калила и Димна и Стефанит и Ихнилат - прилог компаративном проучавању шпанске и српске средњовековне басне"). La autora fue atraída por la muy intensiva y larga recepción que la colección de fábulas y cuentos indios Libro de Calila y Dimna tuvo durante el siglo XIII, tanto en España como en Serbia gracias a las traducciones (directas o indirectas) del árabe. Por ello, la profesora Pavlović-Samurović (1984) reunió y analizó los datos básicos relativos a las traducciones del 
Libro de Calila y Dimna en el área de la lengua serbocroata, así como los datos obtenidos del libro Historia y bibliografía del libro de Calila y Dimna del bibliógrafo español Isidro Montiel, y, también, completó y corrigió ciertos errores que se le habían escapado a Montiel. Tomando en consideración que algunos motivos que han entrado de Panchatantra a través de la traducción árabe en la literatura serbia y española podrían aclarar al menos en parte su evolución diacrónica en diferentes medios sociales y culturales, la autora llevó a cabo un análisis comparativo de las siguientes obras: Fábula de la zorra y el tambor del Panchatanra (la traducción del sanscrito al serbocroata), Kalila i Dimna (la traducción del árabe al serbocroata), Calila y Dimna (la traducción del árabe al español) y Stefanit i Ihnilat (la traducción del griego, hecha a base de la traducción árabe de al-Mukaffa, al serbocroata). Sin comparar los rasgos estilísticos de las obras mencionadas, la profesora Pavlović-Samurović (1984: 96) llegó a la conclusión que el motivo investigado - el hombre cuya apariencia y comportamiento no reflejan su verdadero valor - ha mantenido su concepción original en todas las traducciones y que ha sido elaborado, con desviaciones menores, dentro de la estructura narrativa primaria.

La profesora Ljiljana Pavlović-Samurović (1987) volvió al estudio comparativo de los motivos universales en la ponencia "El motivo del aparecido del otro mundo en el cuento Ero del otro mundo de Vuk Stefanović Karadžić y la obra teatral Pedro de Urdemalas de Miguel de Cervantes” („Мотив повратника са оног света у Вуковој приповеци Еро с оног свијета и у Сервантесовом делу Педро де Урдемалас"). El motivo de un hombre listo que se presenta como un aparecido del otro mundo y engaña hábilmente a los familiares crédulos y torpes del muerto con el fin de conseguir el dinero es registrado bajo el número J 2326 en el Índice de los motivos de la literatura folklórica (Motif Index of Folk Literature) de Stith Thompson y bajo el número T 1540 en el libro Los tipos del cuento folklórico de Antti Aarne y Stith Thompson (Pavlović-Samurović 1987: 139). En su estudio, la profesora Pavlović-Samurović analiza cautelosamente la elaboración de dicho motivo folklórico en el cuento popular serbio que Vuk Stefanović Karadžić publicó en 1821 y en la obra dramática de Cervantes, publicada en 1615. Luego, en base de los resultados obtenidos, la autora interpreta tanto las diferencias entre ambas varian- 
LJILJANA PAVLOVIĆ-SAMUROVIĆ: DESARROLLO Y PERSPECTIVAS DE LOS ESTUDIOS...

tes (surgieron en comunidades étnicas y medios literarios muy diferentes, de diferente forma y extensión - larga y en verso la de Cervantes, corta y en prosa la de Vuk, con un número desigual de participantes, con diferentes grados psicológicos en la construcción de personajes y con características estructurales evidentes) como las calidades esenciales análogas (los protagonistas son figuras bien conocidas del folklore nacional - Ero y Pedro de Urdemalas - cuyos actos se desenvuelven en correspondencia con el idéntico esquema básico del cuento). La ponencia "El motivo del aparecido del otro mundo en el cuento Ero del otro mundo de Vuk Stefanović Karadžić y la obra teatral Pedro de Urdemalas de Miguel de Cervantes" fue mencionada por la profesora Jasna Stojanović (2005: 250) en su libro Cervantes en la literatura serbia (Servantes u srpskoj književnosti), en la parte dedicada a las exploraciones comparativas de la profesora Ljiljana Pavlović-Samurović.

La ponencia "El problema de equivalencia entre el término métrico español el alejandrino y el término métrico serbio aleksandrinac" („Проблем еквиваленције шпанског метричког термина el alejandrino и нашег александринца“), representa una contribución significativa a los estudios de traductología, escrita por la profesora Ljiljana Pavlović-Samurović (1988) y presentada en la XVIII Reunión Científica Internacional de los Eslavistas en los Días de Vuk. Gracias a las traducciones en diferentes idiomas del Libro de Alejandre (Le Roman d'Alexandre), hechas en la Edad Media, el término de verso tomado del nombre del personaje principal de esta obra ha sido transferido a muchos idiomas europeos en los cuales, a pesar del mismo origen etimológico, significa diversos valores silábicos (Pavlović-Samurović 1988: 150). Los resultados del análisis comparativo que se refiere al uso del término dicho en el español y serbio, expuestos en la ponencia, muestran que los términos en la métrica española y serbia que corresponden al nombre francés no son equivalentes, sino que tienen cierta coincidencia en su significado: el término francés l'alexandrin cuyo nombre los escritores del mester de clerecía lo llevaron en el siglo XIII a la terminología métrica española, tuvo doce sílabas, mientras que el verso español era de catorce sílabas; por otro lado, en la poesía serbia el término aleksandrinac empieza a ser utilizado por los poetas modernos (Jovan Dučić, Milan Rakić) para designar versos de doce síla- 
bas creados según el modelo francés medieval. A fin de evitar el equivocado establecimiento de una equivalencia total que no existe entre estos dos términos, la profesora Pavlović-Samurović (1988: 153) considera que el alejandrino español no puede ser traducido al serbio como aleksandrinac, sino como četrnaesterac (el tetradecasílabo) o španski aleksandrinac (el alejandrino español).

En el campo de relaciones interculturales, la profesora Ljiljana Pavlović-Samurović (1989) entró a los finales de los años ochenta del siglo pasado con la ponencia "El príncipe serbio Lázaro en la obra Palinodia de los Turcos (1547) del escritor español Vasco Díaz Tanco” („Кнез Лазар у делу Palinodia de los Turcos [1547] шпанског писца Васка Дијас Танка“), presentada en la XIX Reunión Científica Internacional de los Eslavistas en los Días de Vuk. Vasco Díaz Tanco de Fregenal o Frejenal (1490? - 1573?), distinguido humanista, poeta, dramaturgo e historiador español, que estudió a fondo la historia del imperio otomano, procurando entender las razones de su éxito súbito y sobre todo del continuo fortalecimiento de su poderoso ejército que constituía una amenaza a las naciones cristianas, escribió su amplia obra Palinodia de los Turcos (1547) con intención de estimular a los gobernantes europeos la unión de sus fuerzas en la lucha contra la invasión turca (Pavlović-Samurović 1989: 561-562). Al analizar esta obra, que pertenece a la literatura didáctica renacentista española, la profesora Pavlović-Samurović encontró varios sitios donde se menciona al príncipe serbio Lázaro como uno de los ejemplos más impresionantes de la crueldad turca: Palinodia empieza con un texto corto titulado "Casos notables de fortuna y crueldad" donde se menciona que el Gran Turco Murad I dio la orden de sacarle los ojos al príncipe Lázaro, a raíz de que muriera el gobernante serbio (Pavlović-Samurović 1989: 562) y en el capítulo $V$ está descrita la batalla de Kosovo, aunque el sitio donde tuvo lugar la batalla no se nombra y como año se menciona erróneamente el de 1473 (Pavlović-Samurović 1989: 565). Sin tener pretensiones de entrar en un análisis profundo de la verosimilitud histórica de Palinodia, la autora de la ponencia compara algunos datos relevantes expuestos en este texto con los datos que ofrece la historia oficial y concluye que se trata, en primer lugar, de una obra literaria en la que no deberíamos buscar los hechos históricos, sino la visión artística de los acontecimientos 
LJILJANA PAVLOVIĆ-SAMUROVIĆ: DESARROLLO Y PERSPECTIVAS DE LOS ESTUDIOS...

dramáticos sucedidos en nuestra región que a través del tiempo y varios mediadores llegaron hasta los escritores renacentistas españoles e hicieron parte integral de su visión de la lucha de los países europeos con los conquistadores turcos (Pavlović-Samurović 1989: 568).

A principios de los años noventa apareció otra ponencia de la profesora Ljiljana Pavlović-Samurović (1992) con el título "Andrić sobre Simón Bolívar" („Андрић о Симону Боливару“) que fue dedicada al asunto de las penetraciones interculturales. Ivo Andrić, nuestro famoso escritor que ganó el Premio Nobel en el año 1961, no sólo aprendió español durante su estancia en Madrid donde desempeñó funciones diplomáticas a finales de la tercera década del siglo XX, sino que mostró un vivo interés hacia la cultura y la historia del mundo hispánico, tanto europeo (Anotaciones sobre Goya, 1929; Conversación con Goya, 1935) como el de ultramar (Pavlović-Samurović 1992: 305). La autora de la ponencia analiza el ensayo de Ivo Andrić titulado Simón Bolívar, el Libertador que fue publicado en dos números (el 1 y el 16 de septiembre de 1930) de la prestigiosa revista literaria "Srpski književni glasnik" a raíz de la conmemoración del centenario de la muerte de Bolívar; la versión de este ensayo, hecha por el propio escritor, fue publicada (el 21 de diciembre de 1930) bajo el mismo título en el diario belgradense "Politika". Más tarde, dicho ensayo fue recogido en la colección de los ensayos de Andrić y, en vísperas del bicentenario del nacimiento de Bolívar, el ensayo así como el artículo fueron traducidos al español y publicados en 1982 como un libro suelto en Venezuela con el título Bolívar. La libertad permanente y el prólogo de J. L. Salcedo-Bastardo. Aparte de mencionar todas las fuentes del texto de Andrić en Serbia y su recepción en la patria del Libertador, la profesora Pavlović-Samurović (1992: 309-312) destaca un efectivo conocimiento de la gente y de los acontecimientos sucedidos en Hispanoamérica en este tiempo con el que Andrić presentó a Bolívar como un jefe militar muy valiente y un político obsesionado con la idea de la formación de un estado suramericano unificado que abarcaría a todas las colonias españolas liberadas. La ponencia "Andrić sobre Simón Bolívar" de la profesora Pavlović-Samurović fue observada anteriormente, en el contexto comparativo, juntos con la mirada crítica de la científica Ivanka Udovički sobre dicho ensayo de Ivo Andrić (Dickov 2012: 223-224). 
Los estudios de la profesora Ljiljana Pavlović-Samurović (2000) dedicados a la recepción de la literatura tanto serbia como española abarcan también su ponencia "La poesía popular serbia y los romances españoles en la traducción y la interpretación de John Bowring” („Српске народне песме и шпанске романсе у преводу и тумачењу Џона Бауринга“) presentada en la XXX Reunión Científica Internacional de los Eslavistas en los Días de Vuk. John Bowring (1792-1872) fue economista, diplomático, poeta y filólogo inglés, que estimaba mucho a Vuk Karadžić (Pavlović-Samurović 2000: 138). Él también fue traductor, intérprete y editor de las colecciones de poesía rusa, húngara, polaca, checa y holandesa. Gracias al interés particular que había demostrado por la poesía oral española, especialmente por los romances, y la serbia - lírica y épica, Bowring publicó en 1824 en Londres una antología bajo el título La poesía antigua española y los romances españoles (Ancient Poetry and Romances of Spain) y en 1827 la antología La poesía popular serbia (Servian popular poetry). La profesora Pavlović-Samurović (2000: 149) considera que merece la atención y una investigación pormenorizada el hecho que la poesía popular serbia y española hayan atraído la atención de John Bowring, quien, quizá, había visto en ellas la encarnación de una creación poética fresca, genuina, auténtica demonstración del espíritu popular de una nación.

La última ponencia de Ljiljana Pavlović-Samurović (2004) tiene el título “Marko Car sobre el poeta español Ramón de Campoamor” („Марко Цар о шпанском песнику Рамону де Кампоамору“) у representa un estudio ampliado de dicho tema que ya fuera elaborado por la autora para la V Reunión Científica Internacional de los Eslavistas en los Días de Vuk. Marko Car, crítico serbio, en un ensayo que pertenecía a un subgénero denominado por él como "el perfil literario" publicado en la revista "Letopis Matice Srpske" en 1901, había presentado su interpretación de la personalidad y la herencia literaria de Campoamor (Pavlović-Samurović 2004: 195). En su texto figuraban, según su punto de vista, las características estéticas, estilísticas, éticas formales más importantes de la poesía del escritor español, así como los conceptos fundamentales de su poética de los cuales se ocupaba la profesora Pavlović-Samurović (2004: 196199). Analizando la obra literaria de Campoamor, Car había indicado ciertas analogías entre las ideas del poeta español sobre la función y forma de la poesía y las vigentes en la literatura serbia de los últimos años del 
LIILJANA PAVLOVIĆ-SAMUROVIĆ: DESARROLLO Y PERSPECTIVAS DE LOS ESTUDIOS...

siglo XIX, que podrían justificar su admiración sincera hacia Campoamor y su obra literaria (Pavlović-Samurović 2004: 202).

Durante el período de tres décadas (1974-2004), la profesora Ljiljana Pavlović-Samurović participó muy activamente en el trabajo del Centro Internacional Eslavo de la Facultad de Filología de la Universidad de Belgrado, presentando catorce ponencias en las Reuniones Científicas Internacionales de los Eslavistas en los Días de Vuk. Estas obras abarcan varios temas dedicados a los estudios comparativos, la traductología, la recepción de la literatura serbia y española, así como los estudios de las relaciones interculturales, que por su originalidad y minuciosa manera de elaboración representan una contribución sumamente valiosa al inicio de los estudios hispano-eslavos en Serbia, a la vez ofreciendo muchas perspectivas para su desarrollo en el futuro.

La profesora Ljiljana Pavlović-Samurović fue la fundadora del Departamento de Lengua Española y Literaturas Hispánicas y de la Cátedra de Estudios Ibéricos de la Facultad de Filología de la misma Universidad. También, fue la fundadora de la cervantística serbia, miembro de la Asociacón de Cervantistas y la Asociación Internacional Siglo de Oro. Por su trabajo exhaustivo en el campo de filología hispánica, fue galardonada en 1985 con la Cruz de Oficial de la Orden de Isabel la Católica y la Condecoracón del Águila Azteca en el grado de Placa, y en 2001 obtuvo la Encomienda de la Orden de Isabel la Católica.

\section{BIBLIOGRAFÍA}

Дицков, Весна. „љиљана Павловић-Самуровић (23.7.1935-3.3.2006)“. Прилози за књижевност, језик, историју и фолклор, 71/1-4 (2005): 232-234. Штампано.

Дицков, Весна. „Иво Андрић и хиспанске културе“. Научни састанак слависта у Вукове дане, 41/2 (2012): 211-226. Штампано.

Dickov, Vesna. "Las literaturas hispánicas y el pensamiento crítico y teórico serbio". Colindancias, 5 (2014): 75-102. Štampano.

Павловић-Самуровић, Љиљана. „Мотив девојке-ратника у шпанском Романсеру и у нашој народној поезији“. Научни састанак слависта у Вукове дане, 4/1 (1974): 255-269. Штампано. 
Павловић-Самуровић, Љиљана. „Написи о шпанској књижевности објављени у Летопису у току прве четири деценије XX века“. Научни састанак слависта у Вукове дане, 5 (1975): 317-323. Штампано.

Павловић-Самуровић, Љиљана. „Једно мишљење Менендеса Пидала о југословенској усменој поезији". Научни састанак слависта у Вукове дане, 6/2 (1976): 129-137. Штампано.

Павловић-Самуровић, Љиљана. „О превођењу шпанске именице еl romance на српскохрватски језик". Научни састанак слависта у Вукове дане, 10/2 (1980): 193-200. Штампано.

Павловић-Самуровић, Љиљана. „О превођењу шпанских термина juglar и juglaresco на српскохрватски језик". Научни састанак слависта у Вукове дане, 11/3 (1981): 141-150. Штампано.

Павловић-Самуровић, Љиљана. „Превођење шпанских термина за прозне врсте на српскохрватски језик (fábula и novela)". Научни састанак слависта у Вукове дане, 12/3 (1982): 95-105. Штампано.

Павловић-Самуровић, Љиљана. „Прилог књижевно-језичком проучавању Андрићевих дела и њихово превођење у Шпанији“. Научни састанак слависта у Вукове дане, 13/3 (1983): 111-117. Штампано.

Павловић-Самуровић, Љиљана. „Калила и Димна и Стефанит и Ихнилат - прилог компаративном проучавању шпанске и српске средњовековне басне“. Научни састанак слависта у Вукове дане, 14/3 (1984): 87-97. Штампано.

Павловић-Самуровић, Љиљана. „Мотив повратника са оног света у Вуковој приповеци Еро с оног свијета и у Сервантесовом делу Педро де Урдемалас". Научни састанак слависта у Вукове дане, 17/3 (1987): 139-148. Штампано.

Павловић-Самуровић, Љиљана. „Проблем еквиваленције шпанског метричког термина el alejandrino и нашег александринца“. Научни састанак слависта у Вукове дане, 18/1 (1988): 149-155. Штампано.

Павловић-Самуровић, Љиљана. „Кнез Лазар у делу Palinodia de los Tur$\cos$ (1547) шпанског писца Васка Дијас Танка“. Научни састанак слависта у Вукове дане, 19/1 (1989): 561-569. Штампано.

Павловић-Самуровић, Љиљана. „Андрић о Симону Боливару“. Научни састанак слависта у Вукове дане, 22/1 (1992): 305-315. Штампано.

Павловић-Самуровић, Љиљана. „Српске народне песме и шпанске романсе упреводу и тумачењу Џона Бауринга“. Научни састанак слависта у Вукове дане, 30/2 (2000): 137-149. Штампано. 
LJILJANA PAVLOVIĆ-SAMUROVIĆ: DESARROLLO Y PERSPECTIVAS DE LOS ESTUDIOS...

Павловић-Самуровић, Љиљана. „Марко Цар о шпанском песнику Рамону де Кампоамору“. Научни састанак слависта у Вукове дане, 34/2 (2004): 193-202. Штампано.

Stojanović, Jasna. Servantes u srpskoj književnosti, Beograd: Zavod za udžbenike i nastavna sredstva, 2005. Štampano.

\title{
Vesna Dickov
}

\section{LIILJANA PAVLOVIĆ-SAMUROVIĆ: THE DEVELOPMENT AND PROSPECTS OF HISPANO-SLAVIC STUDIES IN SERBIA}

\begin{abstract}
Summary
Dr. Ljiljana Pavlović-Samurović was the first professor of Hispanic philology at the University of Belgrade in Serbia and the founder of the Department of Spanish Language and Hispanic Literatures as well as a Chair of Iberian Studies at the Faculty of Philology of the same University. She devoted herself mainly to the studies of Hispanic literature, both Spanish - especially the literature of the Golden Age and the work of Miguel de Cervantes Saavedra - and Spanish American literature, examining them from the point of view of the history of literature and critical assessment. A special field of her interest were Hispano-Slavic studies, which she developed through her academic activities related to the International Scientific Meetings of Slavists within Vuk's Days, organized by the International Slavic Center of the Faculty of Philology in Belgrade. The purpose of this paper is to examine - using the analytical method - the articles written by professor Ljiljana Pavlović-Samurović which were published in the Proceedings of the International Scientific Meetings of Slavists within Vuk's Days, with the aim of drawing conclusions about their influence on the development of Hispano-Slavic studies in Serbia as well as on the prospects for the evolution of this type of investigations in the future.
\end{abstract}

Keywords: Ljiljana Pavlović-Samurović (1935-2006), Hispanism in Serbia, University of Belgrade, Faculty of Philology, Chair of Iberian Studies, Department of Spanish Language and Hispanic Literatures, Hispano-Slavic studies, International Slavic Center, International Scientific Meetings of Slavists within Vuk's Days. 